\title{
Electrophysiological Studies in the Critical Care Unit: Investigating Polyneuropathies
}

\author{
Robert Chen
}

\begin{abstract}
Polyneuropathies frequently contribute to ventilator dependency and prolonged stay in the intensive care unit. As clinical examination is often limited in critically ill patients, electrophysiological studies are invaluable in establishing the diagnosis of neuropathy, determining its pathophysiology, severity and in following the patients' progression. Guillain-Barré syndrome (GBS) developing before intensive care unit admission and critical illness polyneuropathy (CIP) developing as a complication of sepsis and multiorgan failure are the commonest causes of neuropathy. Electrophysiological findings in CIP are that of an axonal neuropathy whereas the findings in GBS are usually consistent with a demyelinating neuropathy. Axonal GBS can be distinguished from CIP by the preceding illnesses, slow nerve conduction velocity in some cases, lack of spontaneous activity on the initial needle electromyographic study and cerebrospinal fluid findings.
\end{abstract}

\begin{abstract}
RÉSUMÉ: Études électrophysiologiques à l'unité de soins intensifs: investigation des polyneuropathies. Les polyneuropathies contribuent fréquemment à la dépendance du ventilateur et à la prolongation du séjour à l'unité de soins intensifs (USI). Comme l'examen clinique est souvent limité chez les patients qui sont sévèrement atteints, les études électrophysiologiques sont précieuses pour établir un diagnostic de neuropathie, déterminer sa physiopathologie, sa sévérité et pour suivre l'évolution des patients. Le syndrome de Guillain-Barré (SGB) qui se développe avant l'admission à l'USI et la polyneuropathie des patients dont l'état est critique (PPC) suite à une septicémie et à une défaillance multisystémique sont les causes les plus fréquentes de neuropathie. Les observations électrophysiologiques de la PPC sont celles d'une neuropathie axonale alors aue les observations du SGB sont habituellement compatibles avec une neuropathie démyélinisante. Le SGB axonal peut être différentié de la PPC par les maladies antèrieures, la lenteur de la conduction nerveuse dans certains cas, l'absence d'activité spontanée lors de l'étude électromyographique initiale à l'aiguille et l'examen du liquide céphalorachidien.
\end{abstract}

Can. J. Neurol. Sci. 1998; 25: S32-S35

Polyneuropathies are common among critically ill patients and frequently contribute to ventilator dependency and prolonged intensive care unit (ICU) stay. In this paper, the clinical features and the investigations of critically ill patients with polyneuropathy will be reviewed.

\section{Clinical Features of Polyneuropathy in Critically Ill Patien'ts}

Polyneuropathy may be the primary reason for admission to the ICU or may develop later a secondary complication. Patients with polyneuropathy leading to ICU admission usually have generalized weakness with respiratory involvement, often associated with sensory deficits and autonomic instability. Patients who developed polyneuropathy as a secondary complication often present with failure to wean from the ventilator and diffuse weakness. Important information from the history includes the primary diagnosis and secondary complications, particularly sepsis and multiorgan failure; the dosages and durations of medications administered, especially neuromuscular blocking agents, corticosteroids and antibiotics; the mode and duration of ventilation; procedures and operations performed; and results of previous investigations such as neuroimaging studies and viral serology (e.g., HIV, hepatitis B and C).

Clinical examination in patients with polyneuropathy usually shows symmetrical, sometimes predominantly distal, weakness, decreased muscle tone and diminished deep tendon reflexes. Muscle wasting may be evident in long standing cases. Sensation is often impaired but may be difficult to demonstrate. Plantar responses may be absent due to sensory and motor deficits.

The differential diagnosis for patients in the ICU with diffuse muscle weakness or failure to wean from the ventilator is wide

From the Human Motor Control Section, Medical Neurology Branch, National Institute of Neurological Disorders and Stroke, Bethesda, Maryland, U.S.A. Reprint requests to: Robert Chen, NIH Building 10, Room 5N234, 10 Center Drive, MSC 1430, Bethesda, Maryland 20892-1430 U.S.A. 
Table 1: Neurological Diseases, Other Than Polyneuropathies, That Present With Diffuse Muscle Weakness or Failure to Wean From Ventilator.

Part of the nervous
system affected
Brain

Spinal cord

Patients with spinal shock have paralysis, hypotonia and diminished reflexes that may last for days to weeks.

Motor neuron $\quad$ Motor neuron diseases may present with respiratory failure and ventilator dependency.

Plexus

Plexopathies present as limb weakness and may be due to neoplastic infiltration, trauma, surgery or distal embolization. Phrenic nerve may be involved in brachial plexopathy leading to respiratory insufficiency.

Neuromuscular junction

Myasthenia gravis, Lambert-Eaton myasthenic syndrome, botulism may present with diffuse weakness and predominant respiratory involvement. Prolonged paralysis from non-depolarizing neuromuscular paralyzing agents, often in association with renal or liver failure.

Muscle

Metabolic myopathies, inflammatory myopathies and necrotizing myopathy associated with nondepolarizing muscle paralyzing agents, corticosteroids or sepsis.

and include diseases affecting the brain, spinal cord, motor neuron, ${ }^{1}$ neuromuscular junction ${ }^{2}$ and muscle. The more common causes are listed in Table 1. Metabolic disorders should also be considered. Diffuse weakness may be associated with hypokalemia or hyperkalemia. Hypophosphatemia may resemble Guillain-Barré syndrome (GBS), and can cause diaphragmatic weakness and respiratory failure. The main causes of polyneuropathy in critically ill patients are listed in Table 2. Since critical illness polyneuropathy (CIP) and GBS are by far the most common, they will be discussed in further detail.

\section{Clinical Differences Between CIP and GBS}

CIP is the commonest neuropathy acquired in the ICU, and in a prospective study was present in $70 \%$ of patients with sepsis and multiple organ failure. ${ }^{3}$ Although it may occur as early as the fifth day of ICU stay, more frequently it presents after two weeks with difficulty weaning from the ventilator and diffuse weakness. GBS is often preceded by viral or diarrheal illness, immunization or surgery. Although sepsis and multiorgan failure may be associated with GBS, they occur as a secondary complication. Moreover, in GBS muscle weakness precedes the development of respiratory failure and ventilator dependency, whereas CIP almost invariably develops after respiratory failure from other causes. Cranial nerve involvement is common in GBS but unusual in CIP.

\section{Electrophysiological Studies in the Critical Care Unit}

\section{Technical Aspects}

Electrophysiological studies are particularly useful in critically ill patients as their clinical examination is often limited.
However, technical difficulties are frequently encountered. Electrical interferences from machines and monitors can be minimized by careful skin preparation to reduce impedance, placement of the preamplifier close to the recording site, repositioning or turning off non-essential monitors or machines and the use of a $60 \mathrm{~Hz}$ notch filter if necessary. Some muscles or nerves cannot be studied because of wound or vascular lines. Care should be taken not to stimulate near intravascular lines with direct connection to the heart. Despite these limitations, satisfactory studies can usually be performed in the ICU.

\section{Findings in Critical Illness Polyneuropathy (CIP)}

Electrophysiological findings (Table 3) are that of an axonal neuropathy. ${ }^{3,4}$ The nerve conduction velocities, distal latencies and $F$ wave latencies are usually normal or only minimally reduced. There is no conduction block or temporal dispersion. Sensory nerve action potentials (SNAP) and compound muscle action potentials (CMAP) are markedly reduced, including phrenic CMAP. Needle electromyography (EMG) shows fibrillations and positive sharp waves. The number of voluntary motor units is diminished and they are of normal or small size. With recovery, CMAP and SNAP amplitudes gradually return to normal, abnormal spontaneous activities disappear and motor units become polyphasic, suggestive of reinnervation. Repetitive $(3 \mathrm{~Hz})$ nerve stimulation is normal in CIP but should be performed in patients who had received non-depolarizing muscle paralyzing agents, which can cause prolonged muscle paralysis especially in association with hepatic or renal failure. 5.6

\section{Findings in GBS: acute inflammatory demyelinating polyneuropathy (AIDP)}

AIDP is the most frequent form of GBS in North America and Europe and can usually be distinguished from CIP clinically and electrophysiologically. ${ }^{7}$ In AIDP, there is conduction block, reduction of conduction velocities, prolongation of $F$ waves and distal motor latencies, all of which are usually normal in CIP. The CMAP amplitude is also reduced and is the best predictor of outcome among the motor nerve parameters. ${ }^{8}$ The initial needle EMG examination shows much less abnormal spontaneous activity in GBS than CIP. ${ }^{7}$ Repeat nerve conduction and needle EMG studies three to four weeks after the onset of the illness are useful in patients who are slow to improve, as the findings of fibrillations and positive sharp waves secondary to axonal degeneration are associated with a poor prognosis.

\section{Findings in GBS: axonal form}

The axonal variant of $\mathrm{GBS}^{9}$ is relatively rare in North America and Europe, but was recently found to be a common form of GBS in northern China. ${ }^{10,11}$ Distinguishing the axonal form of GBS from CIP is more difficult than for AIDP. Many axonal GBS cases have slow recovery and severe residual disability. ${ }^{9}$ The CMAP and SNAP are usually severely diminished and frequently no response can be elicited from nerve stimulation. ${ }^{9}$ However, stimulation close to the motor point by advancing the stimulation site beyond the usual most distal sites may evoke a larger CMAP. ${ }^{12}$ The conduction velocities are usually difficult to measure because of the small CMAP, and may range from normal ${ }^{10,13}$ to severely reduced. ${ }^{12}$ There is no spontaneous activity on needle EMG initially but it becomes abundant two to four weeks after the onset of the jllness. 
Table 2: More Common Causes of Neuropathy in Critically III Patients.

\begin{tabular}{|c|c|c|c|c|c|}
\hline$\ldots \quad \ldots \ldots \ldots$ & $\begin{array}{l}\text { Axonal } \\
\text { degeneration }\end{array}$ & Demyelination & $\begin{array}{l}\text { Develop before } \\
\text { or after ICU } \\
\text { admission }\end{array}$ & $\begin{array}{l}\text { Frequency } \\
\text { in ICU } \\
\text { patients }\end{array}$ & Associated features \\
\hline $\begin{array}{l}\text { Critical illness } \\
\text { polyneuropathy }\end{array}$ & + & - & After & Common & $\begin{array}{l}\text { Sepsis and multiorgan failure, failure to wean } \\
\text { from ventilator, normal or mildly elevated CSF } \\
\text { protein. }\end{array}$ \\
\hline GBS - AIDP & \pm & + & $\begin{array}{l}\text { Before, } \\
\text { sometimes after }\end{array}$ & Common & $\begin{array}{l}\text { Preceding viral or diahorreal illness, immuniza- } \\
\text { tion, surgery, elevated CSF protein. }\end{array}$ \\
\hline GBS - axonal form & + & $?$ & Before & Occasional & As AIDP, Campylobacter jejuni infection. \\
\hline CIDP & - & + & Before & Occasional & $\begin{array}{l}\text { Prolonged course, relapsing and remitting, } \\
\text { elevated CSF protein. }\end{array}$ \\
\hline Vasculitic neuropathy & + & - & Before & Occasional & $\begin{array}{l}\text { May have mononeuropathy multiplex, some } \\
\text { associated with other autoimmune diseases. }\end{array}$ \\
\hline $\begin{array}{l}\text { Drug induced } \\
\text { neuropathy }\end{array}$ & + & $\begin{array}{c}- \text { (most } \\
\text { drugs) }\end{array}$ & Before or after & Occasional & $\begin{array}{l}\text { Metronidazole, nitrofurantoin, antiviral agents } \\
(\mathrm{ddC}, \mathrm{ddI}) \text { amiodarone, antineoplastic drugs. }\end{array}$ \\
\hline $\begin{array}{l}\text { CMV associated } \\
\text { polyradiculopathy }\end{array}$ & + & - & $\begin{array}{l}\text { Usually before, } \\
\text { sometimes after }\end{array}$ & Occasional & Occurs in AIDS patients. \\
\hline Diabetic neuropathy & + & \pm & Before & Common & Long standing diabetes. May be present with CIP. \\
\hline Uremic neuropathy & + & - & $\begin{array}{l}\text { Before, } \\
\text { sometimes after }\end{array}$ & Occasional & $\begin{array}{l}\text { Occurs in chronic renal failure, stabilize with dial- } \\
\text { ysis and reverses with successful transplantation. } \\
\text { Phrenic nerve frequently affected. }\end{array}$ \\
\hline Hepatic neuropathy & - & + & Before or after & Rare & $\begin{array}{l}\text { Associated with parenchymal liver failure, } \\
\text { predominately sensory and involve lower limbs, } \\
\text { usually mild and subclinical. }\end{array}$ \\
\hline Porphyria & + & - & Before, rarely after & Rare & $\begin{array}{l}\text { Abdominal pain, psychiatric symptoms, family } \\
\text { history. }\end{array}$ \\
\hline Heavy metal poisoning & + & - & Before & Rare & $\begin{array}{l}\text { Lead, arsenic or thallium exposure. Elevated } \\
\text { levels in blood, urine, hair or nails. }\end{array}$ \\
\hline
\end{tabular}

AIDP - acute inflammatory demyelinating polyneuropathy; CIDP - chronic inflammatory demyelinating polyneuropathy; CMV - cytomegalovirus; CSF cerebrospinal fluid; GBS - Guillan-Barré syndrome; + - present; \pm - sometimes present; - absent; ? unknown.

Table 3: Electrophysiological and Nerve Biopsy Features of Critical Illness Polyneuropathy and Guillain-Barté Syndrome Requiring Admission to the Critical Care Unit.

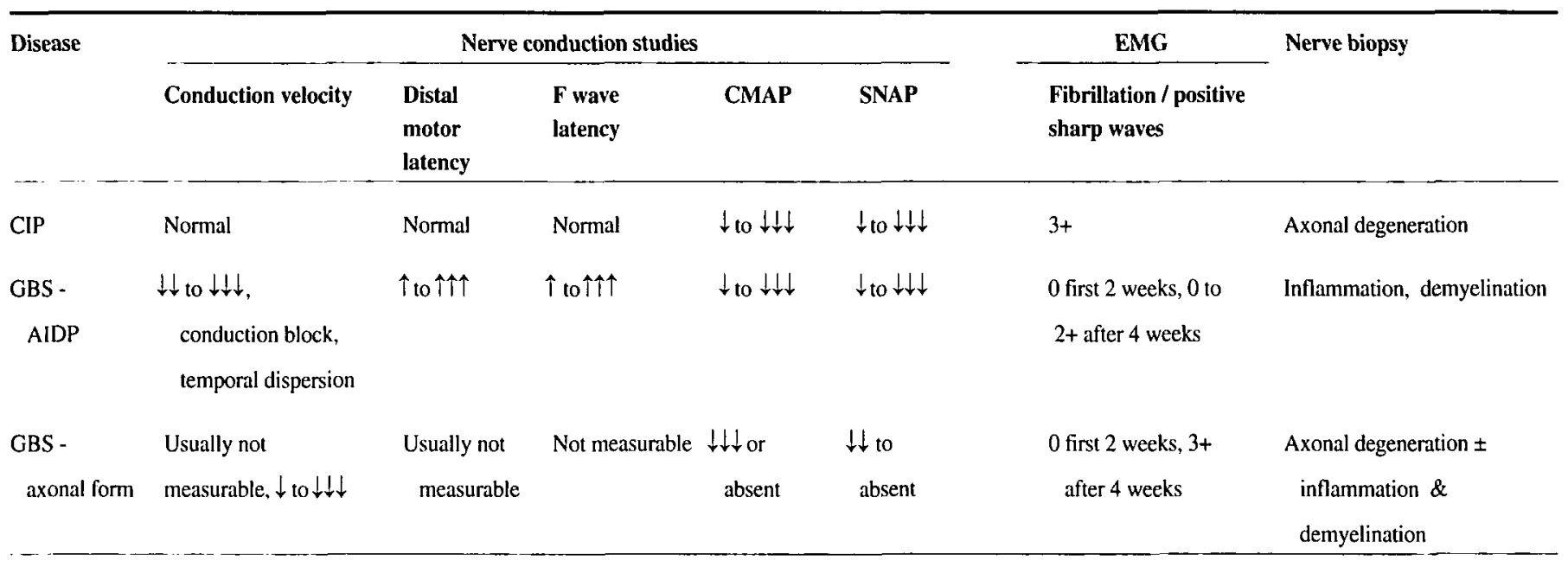

AIDP - acute inflammatory demyelinating polyneuropathy; CMAP - compound muscle action potential; CIP - Critical illness polyneuropathy; EMG - electromyography, GBS - Guillain-Barré syndrome; SNAP - sensory nerve action potential; 0 - none; $1+, 2+, 3+-$ few, moderate, abundant; $\uparrow$, $\uparrow \uparrow, \uparrow \uparrow \uparrow$ - mildly, moderately, markedly increased; $\downarrow, \downarrow \downarrow, \downarrow \downarrow \downarrow$ mildly, moderately, markedly decreased. 


\section{Nerve AND Muscle Biopsy}

Nerve or muscle biopsy is usually not necessary in patients with CIP. However, biopsy is indicated if it is difficult to distinguish neuropathy from myopathy, or differentiate between different neuropathies including vasculitic neuropathy. In CIP, nerve biopsy shows fibre loss and axonal degeneration, without significant inflammation. The distal segments are usually more severely involved than the proximal segments. ${ }^{4}$ In AIDP, the predominant features are demyelination and inflammation although there is sometimes secondary axonal degeneration. There is often severe axonal degeneration without inflammation or demyelination in axonal GBS.9.14 The presence of periaxonal macrophages in some cases ${ }^{10,11}$ suggests that the axon may be the target for immune attack. However, some cases of axonal GBS may be due to axonal degeneration secondary to severe inflammation and demyelination. ${ }^{14}$ Muscle biopsy in CIP sometimes shows muscle fibre necrosis, suggesting concomitant myopathy. ${ }^{4}$

\section{Cerebrospinal, fluid (CSF) and Serology}

In both AIDP and axonal GBS, CSF protein is usually considerably elevated. CSF protein is usually normal but may be mildly elevated in CIP. Preceding infection with Campylobacter jejuni, as demonstrated by serology and stool culture, is associated with axonal degeneration and a poor prognosis for recovery in patients with GBS. ${ }^{15}$

\section{Conclusions}

GBS developing prior to ICU admission and CIP developing after admission are the commonest causes of polyneuropathy in critically ill patients. The cause of the neuropathy can usually be identified by the predisposing illnesses, electrodiagnostic studies, and CSF findings. Further investigations, such as nerve and muscle biopsy, are occasionally necessary to exclude other disorders that may mimic CIP.

\section{REFERENCES}

1. Chen R, Grand'Maison F, Strong MJ, Ramsay DA, Bolton CF Motor neuron disease presenting as acute respiratory failure: a clinical and pathological study. J Neurol Neurosurg Psychiatry 1996; 60: 455-458.

2. Nicolle MW, Stewart DJ, Remtulla H, Chen R, Bolton CF. Lambert-Eaton myasthenic syndrome presenting with severe respiratory failure. Muscle Nerve 1996; 19: 1328-1333.

3. Witt NJ, Zochodne DW, Bolton CF, et al. Peripheral nerve function in sepsis and multiple organ failure. Chest 1991; 99: 176-184.

4. Zochodne DW, Bolton CF, Wells GA, et al. Critical illness polyneuropathy: a complication of sepsis and multiple organ failure. Brain 1987; 110: 819-841.

5. Segredo V, Cladwell JE, Matthay MA, et al. Persistent paralysis in critically ill patients after long-term administration of vecuronium. N Engl J Med 1992; 327: 524-528.

6. Gooch JL, Suchyta MR, Balbierz MJ, Petajan JH, Clemmer TP Prolonged paralysis after treatment with neuromuscular blocking agents. Crit Care Med 1991; 19: 1125-1131.

7. Bolton CF, Laverty DA, Brown JD, et al. Critically ill polyneuropathy: electrophysiological studies and differentiation from Guillain-Barré syndrome. J Neurol Neurosurg Psychiatry 1986; 49: $563-573$

8. Cornblath DR, Mellits ED, Griffin JW, et al. Motor conduction studies in Guillain-Barré sydnrome: description and prognostic value. Ann Neurol 1988; 23: 354-359.

9. Feasby TE, Gilbert JJ, Brown WF, et al. An acute axonal form of Guillain-Barré polyneuropathy. Brain 1986; 109: 1115-1126.

10. Griffin JW, Li CY, Ho TW, et al. Pathology of the motor-sensory axonal Guillain-Barré syndrome. Ann Neurol 1996; 39: 17-28.

11. Griffin JW, Li CY, Ho TW, et al. Guillain-Barre syndrome in northern China. The spectrum of neuropathological changes in clinically defined cases. Brain 1995; 118: 577-595.

12. Brown WF, Feasby TE, Hahn AF. Electrophysiological changes in the acute "axonal" form of Guillain-Barré syndrome. Muscle Nerve 1993; 16: 200-205.

13. McKhann GM, Cornblath DR, Griffin JW, et al. Acute motor axonal neuropathy: a frequent cause of acute flaccid paralysis in China. Ann Neurol 1993; 33: 333-342.

14. Feasby TE, Hahn AF, Brown WF, et al. Severe axonal degeneration in acute Guillain-Barré syndrome: evidence of two different mechanisms? J Neurol Sci 1993; 116: 185-192.

15. Rees JH, Soudain SE, Gregson NA, Hughes RAC. Campylobacter jejuni infection and Guillain-Barré syndrome. $\mathrm{N}$ Engl $\mathbf{J}$ Med 1995; 333: 1374-1379. 